\title{
Serum Magnesium, Calcium and Phosphorus status in Heart Failure patients attending tertiary care center of Nepal.
}

\author{
Bijaya Gautam ${ }^{1}$, Laxman Banstola ${ }^{2}$, Ritu Bashyal ${ }^{3}$ \\ ${ }^{1}$ Dr Bijaya Gautam, Department of Biochemistry, Gandaki Medical College \\ ${ }^{2}$ Dr Laxman Banstola, Department of Pathology, Pokhara Academy of Health Science \\ ${ }^{3}$ Dr Ritu Bashyal, Department of Biochemistry, Patan Academy of Health Science
}

\section{Correspondence:}

Dr Bijaya Gautam, Department of Biochemistry, Gandaki Medical College

Email: beej-gautam@hotmail.com

Article received : $2^{\text {nd }}$ May 2018

Article accepted : $15^{\text {th }}$ Dec. 2019

\section{ABSTRACT}

\section{Background:}

Lack of proper diet and use of different medications in heart failure contributes to electrolyte imbalance. Due to absence of routine measurement, their abnormalities are not recognized. This study is an attempt to portrait a picture of serum levels of electrolytes in heart failure patients Materials and Methods: 102 heart failure patients were enrolled in this study over 6 months period. Serum levels of magnesium, calcium, phosphorus, sodium and albumin were measured. SPSS ver. 20.0 was used to analyze the data. Analysis of Variance was used to find mean differences and Pearson's correlation was used to establish the correlation. Results: Majority of patient fell under New York Heart Association (NYHA) class II and had isolated systolic heart failure. Mean serum values of sodium and magnesium were below the reference range. Mean values of serum sodium, magnesium and corrected calcium was less in patients receiving diuretics and digitalis. Likewise, serum phosphorus was more with diuretics and digitalis use. Also, serum sodium was less in Acetylcholine Eseterose (ACE) inhibitors use. Isolated diastolic heart failure patients had least serum calcium values. Although, serum sodium and magnesium value in heart failure patients was positively correlated, was not statistically significant. Conclusion: This study showed that low serum sodium and magnesium values are frequently associated in heart failure. Disturbances in other serum electrolytes could also be other cause of complications in heart failure which are not under routine investigation. Identification and correction of these disturbances could have significant impact. However, further studies are required to reinforce this idea.

Key words: ACE inhibitors; Calcium; Digitalis; Diuretics; Heart failure; Magnesium; Phosphorus; Sodium 


\section{INTRODUCTION}

Frequent electrolyte abnormalities encountered in chronic congestive heart failure (CHF) are hypomagnesemia, hypokalemia \& hyponatremia. Among these, magnesium and potassium may contribute to the high mortality and sudden death. ${ }^{1}$ Deficiency of these cations occurs as a result of reduced intake or increased loses. Hypomagnesemia is often associated with imbalance of electrolytes like sodium, potassium and calcium. As magnesium serves as a cofactor in several important transporters, deficiency can lead to increased intracellular sodium and calcium concentrations, both of which can lead to increased peripheral resistance and vasospasm. ${ }^{2-3}$ Altered expression and activity of calcium-related proteins are associated with cardiac dysfunction. ${ }^{4-5}$ Hyperphosphatemia may influence Cardio Vascular Disease (CVD) risk through vascular calcification, myocardial fibrosis, and development of left ventricular hypertrophy. ${ }^{6-8}$

The association between serum electrolytes and heart failure patients has not been established so far, in this tertiary center as per the knowledge of the researcher. Thus this study aims to assess the electrolyte status, determine their association in patient with Heart Failure (HF) and hence advocate the need of regular electrolyte monitoring during course of management.

\section{MATERIAL AND METHOD}

A total of 102 heart failure patients admitted under department of cardiology, Manmohan Cardiothoracic Vascular and Transplant Centre (MCVTC) were enrolled in this study over 6 months period between March and August 2015. Diagnosis of heart failure was based on the findings of electrocardiogram and echocardiography along with other laboratory parameters like brain natriuretic peptide. Heart failure was classified with New York Heart Association (NYHA) classification and based on left ventricular ejection fraction (LVEF). ${ }^{9-}$ ${ }^{10}$ All patients who presented to the MCVTC between March and August 2015, with HF, who provide written consent for the study were included. Patients with any known malignant disease, acute or chronic inflammatory or infectious disease like sepsis, arthritis or connective tissue disorder, chronic liver disease and renal failure and thyroid disorders were excluded from study. The research protocol was approved by Institutional Review
Board (IRB), Institute of Medicine, Nepal. In this study, non-probability (convenience) sampling was done and a total of 102 patients were included. Blood samples were collected for various tests which were done without financial burden to the patient. During this study, there was no risk for human participants and no interventions were carried out.

A performa sheet was filled at the ward, ICU and CCU with a detailed history of the patient including the chief complaint, past and present medical history, drug history and vitals. Then $5 \mathrm{ml}$ of blood was drawn from the patients under aseptic condition. The blood was taken to the laboratory within 2 hours and centrifuged at $4000 \mathrm{rpm}$ for 5 minutes, aliquotted and stored at -200 C until analysis. Serum levels of magnesium (total), calcium, phosphorus, and albumin were measured in all the patients using fully automated chemistry analyzer, BT 3000, Italy. Serum calcium was adjusted for serum albumin by using following equation: Corrected calcium $=$ measured total calcium $(\mathrm{mg} / \mathrm{dl})+0.8[4-$ serum albumin (g/dl). A serum level of sodium was determined by ion selective electrode method using fully automated electrode analyser EX-D S/N JE A1 5060050, Japan. Statistical analysis of the data was done using SPSS ver. 20.0. Analyses included standard descriptive variable summaries, measures of distribution with frequency tables and quantitative variables expressed in terms of mean $\pm \mathrm{SD}$. Analysis of Variance was used to find mean differences and Pearson's correlation was used to establish the correlation between study variables.

\section{RESULTS}

Of the 102 patients, $65(63.7 \%)$ were males and 37 $(36.3 \%)$ were females. Mean age of presentation was $58.26 \pm 16 \mathrm{yrs}$ and ranged from 10-90 years. Majority were smokers, male were dominant in alcohol consumption and majority of hypertensive were under treatment. In this study we found that smoking, advancing age, diabetes mellitus and hypertension were associated with heart failure occurrence. A greater proportion of the patients received diuretics $(84.3 \%$ ), followed by ACE inhibitors (52.9\%), and digitalis (31.4\%) (Table I).

Majority of the study population (44.1\%) fell under NYHA class II. Moreover, study findings also revealed that approximately $66 \%$ of the selected patients had 
isolated systolic heart failure. Mean serum values of

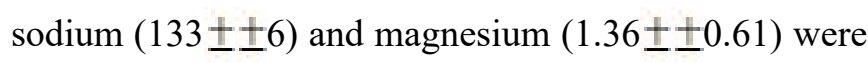
below the reference range as shown in Table II.

Table I: General characteristics of heart failure patients

\begin{tabular}{|l|c|}
\hline \multicolumn{1}{|c|}{ Parameters } & Percentage (\%) \\
\hline Male & 63.7 \\
\hline Smokers & 45.1 \\
\hline Alcoholic & 39.2 \\
\hline Diabetic & 26.5 \\
\hline Hypertensive & 40.2 \\
\hline Hypertensive under treatment & 71.4 \\
\hline Diuretics prescribed & 84.3 \\
\hline Digitalis prescribed & 31.4 \\
\hline ACE Inhibitors prescribed & 52.9 \\
\hline
\end{tabular}

Table II: Distribution of study variables

\begin{tabular}{|l|c|c|c|}
\hline & Mean \pm SD & Median & Range \\
\hline Serum Sodium $(\mathrm{mmol} / \mathrm{L})$ & $133 \pm 6.00$ & 134 & $107-146$ \\
\hline Serum Albumin $(\mathrm{g} / \mathrm{dl})$ & $3.52 \pm 0.62$ & 3.50 & $2.20-5.30$ \\
\hline Serum Magnesium $(\mathrm{mg} / \mathrm{dl})$ & $1.36 \pm 0.61$ & 1.60 & $0.19-2.60$ \\
\hline Serum Phosphorous $(\mathrm{mg} / \mathrm{dl})$ & $4.07 \pm 1.22$ & 4.05 & $1.80-7.60$ \\
\hline Serum Calcium $(\mathrm{mmol} / \mathrm{l})$ & $9.09 \pm 1.51$ & 9.20 & $0.89-11.1$ \\
\hline
\end{tabular}

Mean values of serum sodium, magnesium and corrected calcium were found to be lower among patients receiving diuretics and digitalis than compared to the non-prescribed ones as shown in Table III \& IV.

Table III: Distribution of study variables with diuretics use

\begin{tabular}{|l|c|c|c|}
\hline \begin{tabular}{l} 
Mean Values (Mean \pm \\
\multicolumn{1}{|c|}{ S.D.) }
\end{tabular} & No & Yes & P-Value \\
\hline $\begin{array}{l}\text { Serum Sodium } \\
(\mathrm{mmol} / \mathrm{L})\end{array}$ & $134.00 \pm 3.35$ & $133.06 \pm 6.41$ & 0.57 \\
\hline $\begin{array}{l}\text { Serum Magnesium } \\
(\mathrm{mg} / \mathrm{dl})\end{array}$ & $1.41 \pm 0.48$ & $1.35 \pm 0.63$ & 0.75 \\
\hline $\begin{array}{l}\text { Serum Phosphorous } \\
(\mathrm{mg} / \mathrm{dl})\end{array}$ & $3.64 \pm 1.08$ & $4.15 \pm 1.23$ & 0.13 \\
\hline $\begin{array}{l}\text { corrected serum } \\
\text { calcium (mg/dl) }\end{array}$ & $9.52 \pm 1.00$ & $9.46 \pm 1.55$ & 0.89 \\
\hline
\end{tabular}

Table IV: Distribution of study variables with digitalis use
\begin{tabular}{|l|c|c|c|}
\hline $\begin{array}{c}\text { Mean Values (Mean } \\
\pm \text { S.D.) }\end{array}$ & No & Yes & P-Value \\
\hline $\begin{array}{l}\text { Serum Sodium } \\
(\mathrm{mmol} / \mathrm{L})\end{array}$ & $133.53 \pm 6.14$ & $132.5 \pm 5.82$ & 0.43 \\
\hline $\begin{array}{l}\text { Serum Magnesium (mg) } \\
\text { dl) }\end{array}$ & $1.42 \pm 0.59$ & $1.23 \pm 0.64$ & 0.13 \\
\hline $\begin{array}{l}\text { Serum Phosphorous } \\
\text { (mg/dl) }\end{array}$ & $3.97 \pm 1.23$ & $4.30 \pm 1.19$ & 0.21 \\
\hline $\begin{array}{l}\text { Corrected serum } \\
\text { calcium (mg/dl) }\end{array}$ & $9.62 \pm 1.31$ & $9.14 \pm 1.77$ & 0.13 \\
\hline
\end{tabular}

Likewise, mean value of serum phosphorus was higher among those on diuretics and digitalis than compared to those who did not receive any of them. In the similar fashion, mean value of serum sodium was lower among those prescribed ACE inhibitors as compared to those who did not receive AEC inhibitors; but other study variables had opposite effect (Table V).

Table V: Distribution of study variables with ACE inhibitors use

\begin{tabular}{|l|c|c|c|}
\hline \multicolumn{1}{|c|}{$\begin{array}{c}\text { Mean Values } \\
(\text { Mean } \pm \text { S.D. })\end{array}$} & No & Yes & P-Value \\
\hline $\begin{array}{l}\text { Serum Sodium } \\
(\mathrm{mmol} / \mathrm{L})\end{array}$ & $134.10 \pm 6.18$ & $132.41 \pm 5.84$ & 0.16 \\
\hline $\begin{array}{l}\text { Serum Magnesium } \\
(\mathrm{mg} / \mathrm{dl})\end{array}$ & $1.34 \pm 0.69$ & $1.38 \pm 0.53$ & 0.69 \\
\hline $\begin{array}{l}\text { Serum Phosphorous } \\
(\mathrm{mg} / \mathrm{dl})\end{array}$ & $4.07 \pm 1.40$ & $4.08 \pm 1.05$ & 0.96 \\
\hline $\begin{array}{l}\text { Corrected serum } \\
\text { calcium }(\mathrm{mg} / \mathrm{dl})\end{array}$ & $9.45 \pm 1.60$ & $9.49 \pm 1.37$ & 0.88 \\
\hline
\end{tabular}

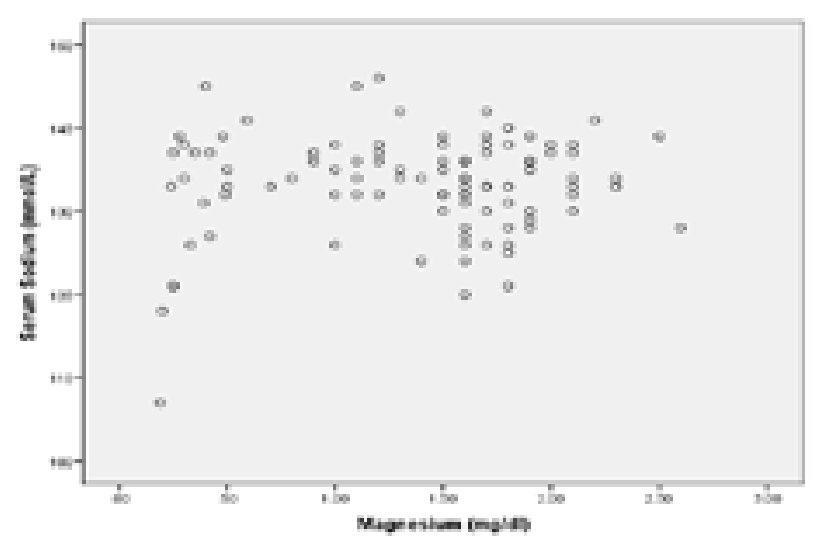


Although, serum sodium and magnesium value in heart failure patients was positively correlated, was not statistically significant (Pearson's $r=0.1, p=0.32)$ (Fig I).

Fig I: scatter plot showing relation between serum sodium and magnesium

Isolated diastolic heart failure patients had least serum calcium values (Table VI).

Table VI: Distribution of study variables with $\mathbf{H F}$ types

\begin{tabular}{|c|c|c|c|c|}
\hline $\begin{array}{c}\text { Mean } \\
\text { Values } \\
\text { (Mean } \pm \\
\text { S.D.) }\end{array}$ & $\begin{array}{c}\text { Isolated } \\
\text { systolic } \\
\text { HF }\end{array}$ & $\begin{array}{c}\text { Isolated } \\
\text { diastolic } \\
\text { HF }\end{array}$ & $\begin{array}{c}\text { Both } \\
\text { systolic } \\
\text { and } \\
\text { diastolic }\end{array}$ & $\begin{array}{c}\text { P- } \\
\text { Value }\end{array}$ \\
\hline $\begin{array}{c}\text { Serum } \\
\text { Sodium } \\
\text { (mmol/L) }\end{array}$ & $\begin{array}{c}133.58 \\
\pm 6.72\end{array}$ & $\begin{array}{c}131.16 \pm \\
5.16\end{array}$ & $\begin{array}{c}134.06 \pm \\
2.74\end{array}$ & 0.25 \\
\hline $\begin{array}{c}\text { Magnesium } \\
\text { (mg/dl) }\end{array}$ & $\begin{array}{c}1.34 \pm \\
0.60\end{array}$ & $\begin{array}{c}1.29 \pm \\
0.67\end{array}$ & $\begin{array}{c}1.51 \pm \\
0.56\end{array}$ & 0.52 \\
\hline $\begin{array}{c}\text { Phosphorous } \\
\text { (mg/dl) }\end{array}$ & $\begin{array}{c}4.07 \pm \\
1.29\end{array}$ & $\begin{array}{c}4.17 \pm \\
1.16\end{array}$ & $\begin{array}{c}3.95 \pm \\
1.04\end{array}$ & 0.87 \\
\hline $\begin{array}{c}\text { Serum } \\
\text { calcium } \\
\text { (mg/dl) }\end{array}$ & $9.28 \pm$ & $7.99 \pm$ & $9.56 \pm$ & $0.001^{* * *}$ \\
\hline $\begin{array}{c}\text { Corrected } \\
\text { calcium } \\
\text { (mg/dl) }\end{array}$ & $9.63 \pm$ & $8.53 \pm$ & $9.94 \pm$ & $0.006^{* * *}$ \\
\hline Indiate & 2.30 & 1.11 & \\
\hline
\end{tabular}

*** Indicate significant different at 0.01 level of significance from ANOVA test.

\section{DISCUSSION}

Heart failure has been singled out as an epidemic and is a staggering clinical and public health problem, associated with significant mortality, morbidity, and healthcare expenditures, particularly among those aged 65 and older. ${ }^{11}$ Despite progress in reducing HF-related mortality, hospitalizations for HF remain very frequent and rates of readmissions continuing to rise. ${ }^{11}$ Using standardized criteria, the incidence of HF in an earlier study from Framingham was between 1.4 and 2.3 per 1000/year among persons 29 to 79 years old. ${ }^{12}$ In support of this finding, our study also depicted that $92.1 \%$ of HF patients were between 21 to 80 years of age.

Electrolyte and acid-base abnormalities are a frequent and potentially dangerous complication in subjects with congestive heart failure. This may be due either to the pathophysiological alterations present in the heart failure state leading to neurohumoral activation, or to the adverse events of therapy with diuretics, cardiac glycosides, and ACE inhibitors. ${ }^{13}$ Subjects with heart failure may show hyponatremia, magnesium, and potassium deficiencies; the latter two play a pivotal role in the development of cardiac arrhythmias. The early identification of these alterations and the knowledge of the pathophysiological mechanisms are very useful for the management of this patients. ${ }^{13}$

Hyponatremia is considered an important risk factor for poor outcome, magnesium has only rarely been considered as independent risk factor for poor outcome in CHF patients. However, magnesium is essential for normal functioning of the cardiovascular system and hypomagnesemia is a common condition in hospitalized patients. ${ }^{14}$ In this study the mean values of serum sodium $(133 \pm 6.0)$ and serum magnesium $(1.36 \pm 0.61)$ were below the reference range. There is also confirmation that the effective correction of magnesium disturbances is favorable in CHFsubjects..$^{15}$ Else, serum magnesium $\leq 2 \mathrm{mEq} / \mathrm{L}$ was associated with increased cardiovascular mortality in patients with chronic heart failure. ${ }^{16}$ In the setting of CHF, magnesium depletion stems from reduced dietary intake, altered distribution of the ion, and renal losses. It should also be considered that edematous states, involving the intestinal mucosa, might interfere with the absorption of microelements, such as magnesium. Respiratory alkalosis may produce a decrease in serum magnesium due to a shift of magnesium inside the intracellular compartment. ${ }^{17}$

Diuretics (loop-acting diuretics in particular) produce most of renal magnesium loss, especially in the volume expanded setting of CHF and in associated hyperaldosteronism. ${ }^{17}$ In our case also mean values in case of diuretic use $(1.35 \pm 0.63)$ was lower than the values among non prescribed patients $(1.41 \pm 0.48)$ but the mean difference was not statistically significant, although values were below the reference range.

Digoxin directly limits the renal tubular reabsorption of magnesium, therefore increasing magnesium excretion; a low magnesium concentration increases the action of cardiac glycoside. ${ }^{13}$ Our study results are in accordance 
with this finding which also showed that the mean value was lower among the digoxin users $(1.23 \pm 0.64)$ as compared to the non-users $(1.42 \pm 0.59)$ but the difference was not statistically significant, although values were below the reference range.

Angiotensin converting enzyme inhibitors should have all the advantages of conventional vasodilators in the treatment of cardiac failure together with several substantial additional benefits. Angiotensin II is an important stimulus to aldosterone secretion, ${ }^{18}$ and lowering plasma angiotensin II by angiotensin converting enzyme inhibition should reduce aldosterone secretion and thus facilitate diuresis while also correcting any deficiency of potassium and magnesium associated with diuretic therapy and aldosterone excess. ${ }^{19}$ In this study, those patients receiving ACE inhibitors had higher mean serum value $(1.38 \pm 0.53)$ than those not receiving them $(1.34 \pm 0.69)$, but the difference was not statistically significant.

Mild-to moderate hyponatremia is generally present in $10 \%$ of HF subjects. ${ }^{20}$ In this study, mean value of sodium $(133 \pm 6.0)$, which is indication of hyponatremia.

In the OPTIME-CHF (Outcomes of a Prospective Trial of Intravenous Milrinone for Exacerbations of Chronic Heart Failure) trial, $27 \%$ of subjects show serum sodium concentrations ranging between 132 and $135 \mathrm{mEq} / \mathrm{L}^{21}$ while in the ESCAPE (Evaluation Study of Congestive Heart Failure and Pulmonary Artery Catheterization Effectiveness) trial, $18 \%$ of the subjects had persistent hyponatremia throughout their hospitalization, defined as serum sodium below 134 $\mathrm{mEq} / \mathrm{L}$.

Diuretics are one of the most common causes of drugs induced hyponatremia; Although thiazide diuretics are most often implicated, also non-thiazide agents, such as furosemide, spironolactone, and indapamide, have been associated with hyponatremia. ${ }^{22}$ In this study mean value in diuretics prescribed patients $(133.06 \pm 6.41)$ was less than non prescribed patients $(134.0 \pm 3.35)$, although the difference was not statistically significant. In everyday practice, HF patients usually receive ACE Inhibitors(ACEIs), $\beta$-blockers, and aldosterone antagonists without the measurement of baseline calcium levels. The effect of maximizing HF therapy on serum calcium levels remains unknown and the published guidelines do not recommend any specific therapy in patients with abnormal levels observed during escalation of HF therapy. An association between abnormal serum calcium levels during therapy maximization and clinical outcome has not been investigated so far. ${ }^{23}$

In this study, mean serum value of calcium is within reference normal range for three different class of heart failure. But the mean value of diastolic heart failure (7.99 \pm 2.52 ) differed significantly with the mean values of systolic $(9.28 \pm 1.02)$ and combined form $(9.56 \pm 1.09)$. Left ventricular (LV) diastolic dysfunction in patients with chronic kidney disease (CKD) is of a complex nature and is mostly associated. ${ }^{24}$ In CKD patients, depending on the stage of the disease, the biochemical disturbances are dominated by a decreased level of serum $\mathrm{Ca}$, especially its ionized fraction $\left(\mathrm{Ca}^{2+}\right)$ in plasma. In this study renal failure patients were excluded, so its value might been fall in normal reference range, but mean values of diastolic heart failure was relatively less than that of other two forms.

A study by Rozentryt $\mathrm{P}$ et al. analyzed predictors of hypo and hyper phosphatemia and relation to prognosis. Hypophosphatemia was associated with better response to therapy, was more prevalent in milder HF, and the association was independent of age, sex, BMI, etiology of $\mathrm{HF}$, kidney function and the use of diuretics. Patients with hyperphosphatemia on top of optimal therapy responded worse to treatment. ${ }^{23}$ The prognostic impact of serum phosphorus abnormalities remains to be established. In this study mean value of serum phosphorus was within the normal range and renal disease was excluded.

\section{CONCLUSION}

CHF subjects develop electrolyte abnormalities due to several pathophysiological mechanisms. Their incidence is often correlated with the severity of cardiac dysfunction; furthermore, these imbalances are associated with a poor prognosis. Many of these metabolic derangements are drug-induced; therefore, these subjects need close monitoring. When treating CHF, one must consider how to prevent and to correct electrolyte imbalances and to prolong patient better survival. Disturbances in other electrolytes could also be other cause of complications in heart failure which are not under routine investigation. Identification and correction of these disturbances could have significant impact in patient outcome. However, 
further studies are required to reinforce this idea.

\section{Acknowledgment}

We would like to thank all the faculties and staff of Department of Biochemistry, IOM and of MCVTC and all patients who participated in this study.

\section{REFERENCES}

1. Packer M, Gottlieb SS, Blum MA. Immediate and long-term pathophysiologic mechanisms underlying the genesis of sudden cardiac death in patients with congestive heart failure. The American journal of medicine. 1987;82(3a):4-10.

2. Kolte D, Vijayaraghavan K, Khera S, Sica DA, Frishman WH. Role of magnesium in cardiovascular diseases. Cardiology in review. 2014;22(4):182-92.

3. Madden JA, Smith GA, Llaurado JG. Myocardial $\mathrm{K}$ kinetics in rats on $\mathrm{Mg}$-deficient diet. Journal of the American College of Nutrition. 1982;1(4):3239.

4. Viola HM, Hool LC. How does calcium regulate mitochondrial energetics in the heart? - new insights. Heart, lung \& circulation. 2014;23(7):602-9.

5. Kho C, Lee A, Hajjar RJ. Altered sarcoplasmic reticulum calcium cycling--targets for heart failure therapy. Nature reviews Cardiology. 2012;9(12):717-33.

6. Foley RN, Collins AJ, Herzog CA, Ishani A, Kalra PA. Serum phosphorus levels associate with coronary atherosclerosis in young adults. Journal of the American Society of Nephrology : JASN. 2009;20(2):397-404.

7. Amann K, Tornig J, Kugel B, Gross ML, Tyralla K, El-Shakmak A, et al. Hyperphosphatemia aggravates cardiac fibrosis and microvascular disease in experimental uremia. Kidney international. 2003;63(4):1296-301.

8. Foley RN, Collins AJ, Herzog CA, Ishani A, Kalra PA. Serum phosphate and left ventricular hypertrophy in young adults: the coronary artery risk development in young adults study. Kidney \& blood pressure research. 2009;32(1):37-44.

9. The Nomenclature and Criteria for Diagnosis of the Heart and Great Vessels. The Criteria Commitee of the New York Heart Association. 9th ed. Boston: Little, Brown \& Co.; 1994. p. 253-6.

10. Cardiology ACo. Left Ventricular Ejection Fraction (LVEF) Assessment in Out Patients: Pinnacle Network; 2002. Available from: http:// www.cardiosource.org/en/Science-And-Quality/ Clinical-Tools/Heart-Failure-Practice-Solutions/ HF-Toolkit/Left-Ventricular-Ejection-Fraction. aspx.

11. Roger VL. Epidemiology of heart failure. Circulation research. 2013;113(6):646-59.

12. McKee PA, Castelli WP, McNamara PM, Kannel WB. The natural history of congestive heart failure: the Framingham study. The New England journal of medicine. 1971;285(26):1441-6.

13. Urso C, Brucculeri S, Caimi G. Acid-base and electrolyte abnormalities in heart failure: pathophysiology and implications. Heart failure reviews. 2015;20(4):493-503.

14. Altura BT, Wilimzig C, Trnovec T, Nyulassy S, Altura BM. Comparative effects of a Mg-enriched diet and different orally administered magnesium oxide preparations on ionized $\mathrm{Mg}, \mathrm{Mg}$ metabolism and electrolytes in serum of human volunteers. Journal of the American College of Nutrition. 1994;13(5):447-54.

15. Douban S, Brodsky MA, Whang DD, Whang R. Significance of magnesium in congestive heart failure. American heart journal. 1996;132(3):664-71.

16. Adamopoulos C, Pitt B, Sui X, Love TE, Zannad F, Ahmed A. Low serum magnesium and cardiovascular mortality in chronic heart failure: a propensity-matched study. International journal of cardiology. 2009;136(3):270-7.

17. Wester PO. Electrolyte balance in heart failure and the role for magnesium ions. The American journal of cardiology. 1992;70(10):44C-9C.

18. Bravo EL. Regulation of aldosterone secretion: current concepts and newer aspects. Advances in nephrology from the Necker Hospital. 1977;7:105-20.

19. Cleland JG, Dargie HJ, Ball SG, Gillen G, Hodsman GP, Morton JJ, et al. Effects of enalapril in heart failure: a double blind study of effects on 
exercise performance, renal function, hormones, and metabolic state. British heart journal. 1985;54(3):305-12.

20. Sica DA. Hyponatremia and heart failure-pathophysiology and implications. Congestive heart failure. 2005;11(5):274-7.

21. Klein L, O'Connor CM, Leimberger JD, GattisStough W, Pina IL, Felker GM, et al. Lower serum sodium is associated with increased short-term mortality in hospitalized patients with worsening heart failure: results from the Outcomes of a Prospective Trial of Intravenous Milrinone for Exacerbations of Chronic Heart Failure (OPTIME-CHF) study. Circulation. 2005;111(19):2454-60.

22. Chapman MD, Hanrahan R, McEwen J, Marley JE. Hyponatraemia and hypokalaemia due to indapamide. The Medical journal of Australia. 2002;176(5):219-21.

23. Rozentryt P, Niedziela JT, Hudzik B, Doehner W, Jankowska EA, Nowak J, et al. Abnormal serum calcium levels are associated with clinical response to maximization of heart failure therapy. Polskie Archiwum Medycyny Wewnetrznej. 2015;125(1-2):54-64

24. Gromadzinski L, Januszko-Giergielewicz B, Pruszczyk P. Hypocalcemia is related to left ventricular diastolic dysfunction in patients with chronic kidney disease. Journal of cardiology. 2014;63(3):198-204. 